\title{
Architecture of high-rise buildings as a brand of the modern Kazakhstan
}

\author{
Gulnara Abdrassilova ${ }^{1, *}$, Nina Kozbagarova $^{1}$, Ainagul Tuyakayeva ${ }^{1}$ \\ ${ }^{1}$ Kazakh Leading Academy of Architecture and Civil Engineering AO (JSC), Ryskulbekov street, 28, \\ Almaty, Republic of Kazakhstan, 050043
}

\begin{abstract}
Using practical examples article reviews urban-planning and space-planning features of design and construction of high-rise buildings in Kazakhstan conditions; methods are identified that provide for structural stability against wind and seismic loads based on innovative technical and technological solutions. Article authors stress out the fashion function of high-rise buildings in the new capital of Kazakhstan, the Astana city.
\end{abstract}

\section{Introduction}

High-rise buildings in modern cities are active elements of the space environment, supporting the formation of the city's unique silhouette. At the same time they are the objects representing the technological progress, social-economic achievements of individual construction companies, as well as the country's achievements as a whole.

Each high-rise building solves unique spectrum of tasks based on the urban conditions and individual features of the construction site [1,2]. Urban tasks are connected with formation of the cities' environment, functional organization of public spaces, tasks of creating the compositional dominants and landmarks, important issues of increasing the attractiveness of the construction, etc. Apart from those named are engineering tasks related to composition of the soil, temperature fluctuations, wind power, seismic conditions $[3,4]$. High-rise building also requires significant resources during its operation in order to maintain communication systems, firefighting systems, people evacuation systems in case of emergency, optimization of resources' energy consumption, etc.

Article authors aim to identify features of designing and constructing high-rise buildings in the climatic conditions of Kazakhstan.

Sharply continental climate over the whole territory of Kazakhstan and high seismic activity in the South and East parts of the country are serious challenges for high-rise construction. However, prestige issues and the need to increase financial-economical, investment and tourist potential of the young country dictate the breakthrough development in this branch of architecture.

Up until now architecture theory of Kazakhstan has not comprehensibly studied highrise architecture. Materials primarily focus on individual aspects, descriptions of

\footnotetext{
*Corresponding author: g.abdrassilova@,kazgasa.kz
} 
architectural features of particular high-rise buildings [5-7]. The issue of high-rise construction is reflected in depth in the works of engineers specializing in the issues of seismic stability of structures [8-13].

Modern Kazakhstan has become a platform for implementing fresh new engineering and architectural solutions in high-rise buildings. High-rise buildings are mostly concentrated in Astana, the new capital of the country, which through the use of worldrenowned technologies in design and construction positions itself as a modern, innovative city $[14,15]$.

\section{Methods}

During the study of the high-rise buildings architecture in Kazakhstan the authors of the article had used literary sources, project materials, regulatory documents. Research methods are: comparative analysis of the sources, on-site assessment of the objects.

\section{Analysis}

Almaty is located at the foothill of Zailiyski Alatau mountains. Mountain gorges supply the air mass, ventilating the city and releasing it from smog. The location of Almaty in a semiclosed intermountain valley in the wind-shadow region is the reason for city's windless weather almost all year round, which contributes for build-up of the exhaust gasses in the form of smog in the city's air basin. In recent years the issue is getting more complicated by the move of construction zone up the mountain slopes obstructing the natural movement paths of mountain air into the valley towards the city.

Peculiarities of the urban aerodynamics related to katabatic drain of mountain air masses; limitedness of the city territories amplified by the high seismic activity have long determined the number of storeys in urban construction - not higher than 12 storeys.

First high-rise building in the city, the 25-storey hotel 'Kazakhstan', was erected in 1977 defying the opinion of the impossibility of city's vertical growth. Hotel's ellipsoid building had become the impressive dominant against the backdrop and had aptly complimented the city center's silhouette (Fig. 1). Vertical array of bow windows, giving the building its simplicity and delicacy, ends with high attic in the form of aureate crown made of anodized aluminium $[16,17]$. When designing the hotel, factors were taken into account determining its shape and comfort of residency (direction of the winds, angle of sunlight incidence, etc.) Hotel was planned to accommodate 1,000 guests, included 497 one-, two- and three-room suites. Certain tightness of the rooms (according to the contemporary standards one-room suite area was 12 square meters) was due to predefined dimensions of the hotel's rigid structure. For de luxe suites cavities in the rigid structure were used [18].

Construction of the hotel in the 9-point seismic zone mandated use of then contemporary achievements of construction science and technology. To provide for hotel's earthquake-resistance the then innovative construction method was used - reinforced concrete monolith, made by climbing formwork technology which was actively used in Japan at the time. Main structural element is the oval-shaped rigidity core. Inside the core are the elevator shafts and engineering communications. From the oval structure the diaphragms are propagated, which are the suite walls [18].

The high-rise part of the hotel is installed onto a two-storey socle building embracing the lobby, savings bank branch, post office, café, restaurant and a conference-hall. The hotel was equipped with modern engineering facilities and high-speed passenger elevators. The lobby is made in the form of open space. Aluminium structures resembling a crown at 
the roof were fixed at the ceiling. By the registration desk the space theme panel was hung. The floor was laid out with black gabbro, labradorite.

Expensive construction materials were used in interior: marble, aluminium, synthetic materials. Walls finished with 'Sochi' plasterwork (two layers of marble chips of the same colour but different shades) created an elegant pattern. Walls on each floor had their own distinctive colouring. Space theme became primary in the interior design of the high-rise building's hotel beginning from entry lobby on the first floor to the 'Space' restaurant on the hotel's top floor at the mark of 86.1 meters, offering magnificent panorama of the Zailiyski Alatau mountain range.

The then modern construction materials were used in exterior finishing: aluminium panels, limestone. On the main and rear facades light bars were installed onto which aluminium sheets were hung. A layer of insulation material was laid between the bars. Bars shaped zigzag in terms of plasticity gave building the slenderness and lightness. Side facades were coated with light pink Mangyshlak limestone.

The surmounting 'crown' which became the distinctive feature of the hotel have raised a lot of debate [9], but time have confirmed the relevance and artistic value of that component. 'The crown' has appeared as part of the camouflage: the elevator shafts' structure was supposed to be two storey higher than the main building, so that two-storey structure appeared in the very centre of the rooftop. In order to disguise it a metal structure was introduced, 'the crown', which encircled the roof and repeated its facade shape. Each individual toothed element of the metal 'crown' was 10 meters high. At night the hotel's 'crown' lit up with ruby lights which could be seen from every observation point in the city [19]. Not long before the construction was over in 1977 seismic stability tests were held: up on the rooftop the machines were mounted that imitated vibrations, special sensors on the building floors detected the tremors. The building did not get any damage as a result of tests.

The hotel is situated in one of the important urban hubs, at the intersection of Dostyk and Abay avenues. Architectors regard the complex of buildings comprising this urban hub as an example of good solution of urban and composite tasks. The building is orientated along the meridian which provides for good aerodynamic conditions of the area. Searching for idea architectors pursued visual connection of the 'Kazakhstan' hotel's vertical with spread out volume of Palace named after V.I. Lenin (now named the Palace of the Republic) revealing the uniformity of the ensemble of Abay square based on the contrast of the forms. In order to stress out the method of visual interconnection facades' finishing included alike construction materials: light limestone along with finishing by anodized aluminium, that allowed uniformity and lightness to the massive structures.

Thanks to its distinctive look and unorthodox solution in facade finishing the 102-meter high building to these days remains one of the most well-known objects in Almaty and Kazakhstan. The authors (architectors Y.Ratushny, L.Ukhobotov, A.Anchugov, V.Kashtanov, engineers A.Deyev, N.Matviets, T.Zhunussov, A.Tatygulov) created an object that became not only a sight and a symbol of the city but also an example of a unique engineering solution. In 1980 authors were honoured with the State award of Kazakh SSR named after C.Valikhanov. 'Kazakhstan' hotel is an example of engineering art which was not overcome until 2008 when another skyscraper appeared in Almaty, the 'Esentai Tower'.

In recent decade economical conditions and engineering technologies made it possible to construct new high-rise buildings in Almaty, namely the 25-storey multifunctional business complex 'Almaty Towers' (100 meters high) and the 168 meter high 'Esentai Tower'.

Esentai' complex's architecture designed by world-renowned company Skidmore, Owings and Merrill (SOM) and implemented in Almaty in 2008 serves as a vivid example of the use of innovative technologies and accounting for the 'spirit of the place'. Project 
aimed at solving main issues of the construction in Almaty conditions - high seismic activity and low ventilation of city's air basin.

The location of Almaty in a semi-closed intermountain valley in the wind shadow region is the reason for having windless weather in the city almost all year round, which contributes to accumulation of the exhaust gasses in the form of smog in the city's air basin. In recent years the issue is getting more complicated by the move of construction zone up the mountain slopes obstructing the natural movement paths of mountain air into the valley towards the city.

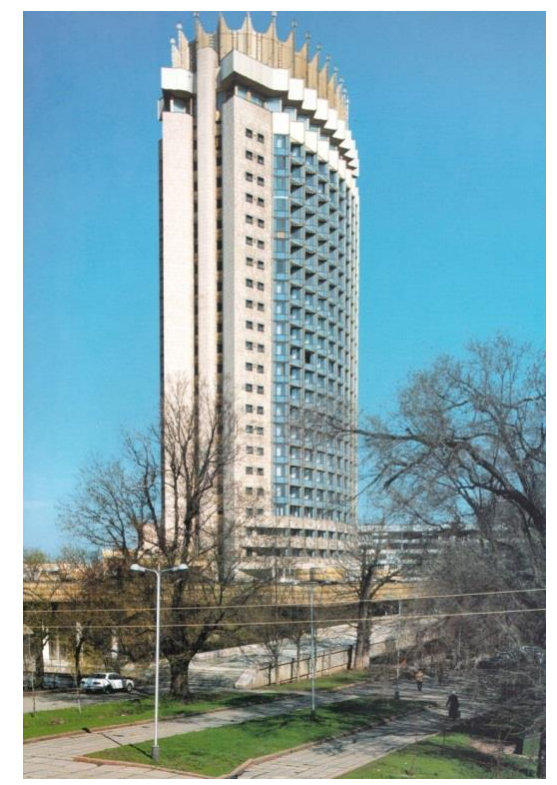

Fig. 1. Hotel 'Kazakhstan', Almaty [22]

'Esentai' complex situated in the foothill region of Almaty solves problem of 'air shadow' of the city with use of architectural tools. SOM proposed use of spacialdimensional solutions forming movement of the air masses. Complex comprises high-rise tower and several residence blocks. Primary element of the complex is the 'Esentai tower'. Lower 14 storeys are occupied by commercial offices, above them is the hotel Ritz-Carlton, upper eight storeys host serviced apartments [20].

Spacial-dimensional solution of the complex is associated with the gorge: narrow gaps between buildings create unique tunnels shaded or lit depending on the time of the day. Interaction of cooled and heated parts of the complex territory creates breezes which move in the space between blocks and form air flows. At the same time between the block gaps the mountain fragments appear and become the part of artistic perception of the complex.

In its project SOM combined progressive western engineering solutions and local natural conditions of Almaty. Composite solution of the complex parts is based on revealing the look of natural surroundings: building with its intriguing shape resembling rocks spreads out under the pressure of mountain breeze. Game of light on the refractive surfaces brings out strict plasticity of the facades. Lapidary shapes of the glass tower, fullness of the territory with sunlight, panoramic view at mountains create special perception of space environment of the complex (Fig. 2).

As in any high-rise building, here in the basis of the composite effect of the form lie innovative engineering-design solutions. Constructively 'Esentai tower' is made in the shape of dimensional system of the core, developed in terms of multisectional rigidity, and rigid 
frames located along the building's perimeter, that have high resistance against seismic loads. Specially for 'Esentai Park' complex Leslie E. Robertson Associates RLLP designed concrete structure with the consideration of probability of highly destructive earthquakes. Dampers were installed in the building allowing it to sway and quench the horizontal loads in case of seismic vibrations. Strict norms and requirements used in the project are significantly tighter than those used when constructing such high-rise buildings in seismically dangerous cities of the world like San Francisco, Los Angeles and Tokyo [21].

In 'Esentai Tower's' architecture the innovative glass was used which does not overheat the building and does not let harmful ultraviolet light through, is of high degree of transparency, made by means of modulating natural crystallized quartz from which the iron was extracted. Glass in the exterior of 'Esentai Tower' accomplished artistic tasks as well: for example, in the lower part of the western facade the glass is as if giving the glare of shimmering water.
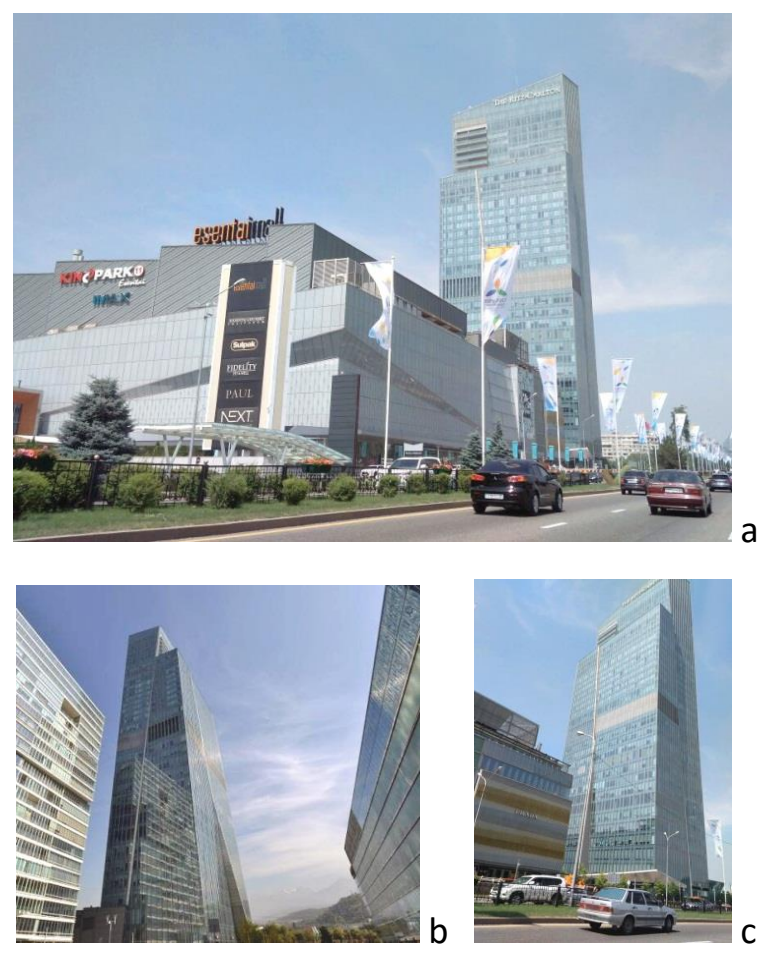

Fig. 2. 'Esentai Tower', Almaty: a - South-West view from Al-Farabi avenue, b - North-West view, c - South-West view, the photos was taken in 2017 [author's source]

Today the highest buildings in Kazakhstan of $100+$ meters in height are mostly concentrated in new capital, Astana (Fig.3). In harsh economic conditions in December, 1997 the move of capital from Almaty to Astana have set an enormous task before architects and constructors - to create a new city meeting the requirements of world standards, that shall become a well-recognizable brand on international arena. It was a method to make way to the world's top rapidly developing cities, win political and economical dividends for the country, a fragment of the mighty soviet empire.

The climate of Astana is sharply-continental, with cold winter (lower than $-40^{\circ} \mathrm{C}$ ) and hot summer (up to $+40^{\circ} \mathrm{C}$ ). Besides intense gusty winds and dramatic yearly temperature fluctuations constructing high-rise buildings in Astana faced yet another huge problem elevated standing groundwater and aggressive soil. Theoretically, harsh climatic conditions 
of Astana did not encourage the birth of a new city. But past 20 years have proved rightness of the President of Kazakhstan N.A. Nazarbayev who had initiated the move of the capital.

In 1998 after the contest for the master-plan of Astana in which Japanese architect Kisho Kurokawa have won, the new capital began its development based on the metabolic model aimed at forming a symbiosis of natural and artificial environments, respecting history of the place, creating green zones inside the city and forest plantations around it [22].

In January, 2002 in order to create a good investment climate and attract money the free economic zone 'Astana - new city' was created, which led to increase in number of local and international companies that invested in building the new capital of Kazakhstan, modern residences, service, trade and amusement sites. Private investors have played a significant role in forming the distinctive architectural look of the new capital of Kazakhstan.

Designers and constructors of Astana had been solving a super-task of building a 21st century city based on achievements of a modern architectural and urban-planning ideas. To have the capital's architectural look match a model city of the third millennium the adopted decisions must have been made in the fairway of world's innovative trends. With this aim prominent modern architects have been invited to design the most significant objects to be erected in Astana. Construction of significant objects forming the look of main avenues and squares was carried out only according to projects that went through the competitive selection process. After the official approval of the new master plan of the capital in 2001 as a 'project representing the philosophy and theoretical postulates of urban planning of 21 st century vigorous works have started to actively implement them, form new planning structure of the city and its architectural look' [23]. Main scope of work was taken to the left bank of Ishim river to form the New center, erect complex of Water-green boulevard buildings, Round plaza, government buildings of the Main square. In 2003 first 36-storey 155-meter high kazakhstani skyscraper, the building of Ministry of transport and communications, was constructed.

In 2006 main architectural ensembles of Astana were finalized (Water-green boulevard, Main square, etc.), construction have started of multifunctional high-rise residences 'Emeral block', 'Northern lights', 'Triumph of Astana' [23].

Height of some of the 'Emerald block' buildings is 200+ meters. Its concept was designed by the architect Roy Varacalli and the Zeidler Partnership Architects (Canada) together with Bazis development company (Kazakhstan). Complex consists of three buildings, 37, 43 and 54-storey high. Starting from 32nd floor area of each consecutive floor increases, building becomes asymmetrical with the rooftop deviating for 15 meters. Given strong wind loads of Astana, Canadian engineers conducted a significant amount of project testing in aerodynamic tube. The highest building of the complex weighing 186 thousand tons is sitting on bored piles at the depth of up to 20 meters and a foundation plate around 3 meters thick.

'Northern Lights' residence situated on Astana's Water-green boulevard includes three units (34, 39 and 44 storeys) and is up to 180 meters high.

Besides residences list of high-rise buildings of Astana includes commercial buildings, trade-amusement centers. Office of the National company 'Kazakhstanskiye zhelezniye dorogi' (Kazakhstan railways), the 'Temir Zholy' tower, a 44-storey 175-meter high skyscraper.

One of the iconic objects of Astana is the 150-meter high trade-amusement complex 'Khan-Shatyr' (architector Norman Foster) which was opened on July 6, 2010. The core of the building's framework is a unique system constituting a tripod - the support for the steel guards system's upper ring with ETFE fixed transparent coating, and lower ring fixating guards at the base of the building. Thanks to special chemical composition coating protects 
the inner space of the complex from dramatic temperature fluctuations and creates a comfortable micro-climate inside the complex.

Total area of the complex is 127,000 square meters. Here numerous trade and amusement complexes are located: supermarket, family part, café and restaurants, cinemas, gyms, aqua park with artificial beach and water pools with wave effect, administrative and commercial offices, 700 car parking lot and many more. Main landmark of 'Khan-Shatyr' is the beach with sea sand, tropical plants and +35 temperature all year round.

'Grand Alatau' complex built in 2009 in historical center of Astana consists of four highrise residence buildings $(20,28,38$ and 43 storeys) connected by a common stylobate. The 43 -storey tower is 144 meters high.

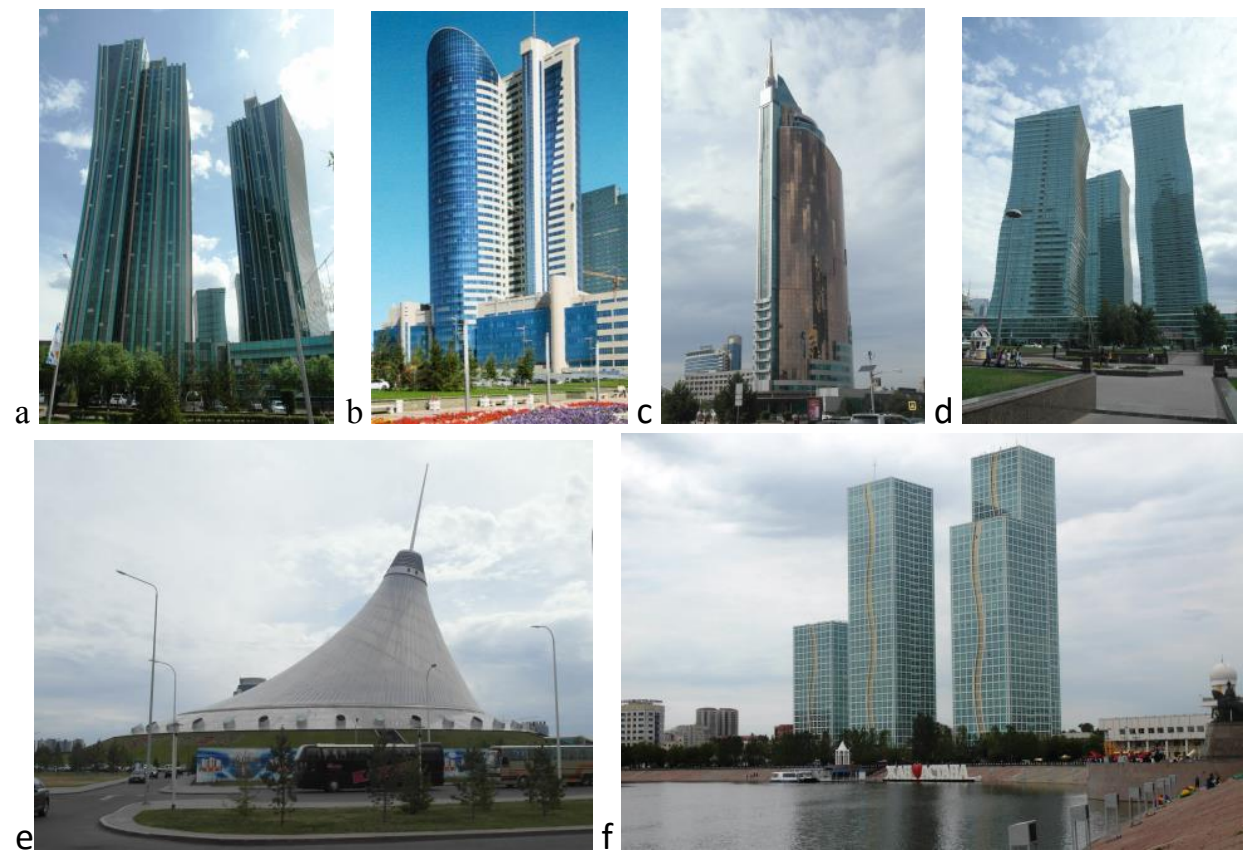

Fig. 3. Examples of high-rise buildings of Astana: a - 'Emerald block' residence complex, 2013, Arch. R.Varacali / Zeidler Partnership Architects; b - 'Temir Zholy' tower, 2009, Arch. T.Abilda [7]; c -'Transport Tower', Ministry of transport and communications of the Republic of Kazakhstan, 2013, Architicture - Bazis company; d - 'Northern Lights' residence complex, 2009, Arch. A.Saumenov, Y.Ezzauu, T.Abilda; e - 'Khan-Shatyr' trade-amusement center, 2010, Arch. Norman Foster; f - 'Grand Alatau' residence, 2008, Arch. S.Mataibekov; the photos was taken in 2017 [author's source]

First decade of the new capital witnessed an unprecedented amplitude and pace of construction works. To allow forming holistic space environment, interconnection of municipal improvement and construction, architects shifted from the 'spot' construction of local parcels to the complex construction of the whole block by single investor. Examples of such complex construction are the residences 'Highvill' and 'Grand Astana' constructed with social and cultural-resort related objects that are necessary for servicing the local residents.

During the years of Astana construction numerous foreign architects participated in designing unique sites of the capital of Kazakhstan: Palace of Peace and Reconciliation (arch. N.Foster), 'Kazakhstan' Central Concert Hall (arch. M.Nicoletti), trade-amusement complex 'Khan-Shatyr' (arch. N.Foster), multifunctional hotel-residence skyscraper complex 'Abu-Dhabi Plaza Astana' (arch. N.Foster), a 216-meter high hotel-commercial 
building (arch. K.Kikutake); 280-meter high hotel-commercial complex (arch. R.Stern), etc. These super-modern buildings and structures of unique architecture implemented at world standard give unmistakable look to the new capital of Kazakhstan [23].

A lot of unique projects were carried out in Astana by the projects of kazakhstani architects: House of the Ministries, construction of the Main square and Round plaza, Water-green boulevard, multistorey residences, museums, commercial buildings, hotels and tradeamusement centers, universities, medical centers and many more [23]. Among them are: 142-meter high residence complex 'Triumph of Astana' (arch. A.Zuyev, N.Boriskin), 180meter high complex 'Northern Lights' (arch. A.Saumenov, Y.Ezzauu, S.Mataibekov), $175-$ meter high tower 'Temir Zholy' (arch. T.Abilda), 144-meter high residence complex 'Grand Alatau' (arch. S.Mataibekov) and others [22].

\section{Results}

Analysis of modern high-rise architecture in Kazakhstan has shown their disposition only in two cities, Almaty and Astana.

High-rise construction in Almaty is complicated due to 9-point seismic activity of the foothill zone. Despite the experience of constructing and operating the hotel 'Kazakhstan' for 40 years has shown that special engineering solutions allow erecting skyscrapers in this city, huge economic expenditures are necessary to support sustainable operations.

An example of innovative approach is the 'Esentai' complex with 'Esentai Tower'. Taking into account the probability of a highly destructive earthquake company Leslie E. Robertson Associates RLLP during construction of the 168-meter high tower used new engineering solutions - multilayer rigidity core and stiff frameworks, placed along the building perimeter and possessing increased endurance against seismic loads; dampers allowing the building to sway in case of seismic vibrations and quench horizontal loads. Authors of 'Esentai Tower' project inserted the site into the local context having reflected in the tower's look mountain ranges, deep gorges, raging rivers [21].

In Astana more than 20 buildings of $100+$ meters high are constructed. Astana skyscrapers not only fulfil their primary function (residence, offices, trade centers) but also demonstrate achievements of the country: in 20 years of building its new capital Kazakhstan has obtained significant political, economical and technological dividends. During that time Astana has become a world-wide recognizable brand symbolizing the dynamic development of Kazakhstan. Country's economy has attracted colossal foreign investments, the infrastructure development has been boosted country-wide, new jobs and production companies have been created. High level of technologies implemented by foreign companies in Astana provides for increase in quality of architectural and engineering solutions.

\section{Discussion}

In today's scientific literature in Kazakhstan the issues of high-rise buildings are considered mainly from the point of view of their engineering stability. Nevertheless skyscrapers are of interest not only in the aspect of innovative construction solutions but also as distinctive architectural objects that serve as prominent dominants in the space environment of the cities, optimize functional organization of valuable city areas.

There are a lot of opponents to building high-rises in Kazakhstan who support their opinion with complex seismic, hydrogeological and other conditions. Contemporary engineering technologies allow implementing the most audacious architectural ideas even in complex seismic conditions. During the construction of high-rise buildings advanced 
geotechnologies were implemented for arranging driven and bored piles in special ground conditions of Astana (Palace of Peace and Reconciliation, Khan-Shatyr, Ministry of transport and communication, etc.) [11]. All of the aforementioned allows forecasting expansion of the high-rises 'park' in the big cities of Kazakhstan.

\section{Conclusion}

The conducted analysis of the experience in design and construction of high-rise buildings in Kazakhstan revealed main requirements to formation of architecture of high-rise buildings:

- the architecture of high-rise buildings is impacted in a complex way made by methods that allow resistance against wind and seismic loads;

- in seismic conditions most widespread structural solution is monolithic framework consisting of the rigidity core, fortified foundation and rigidity diaphragms, as well as tools 'quenching' seismic tremors - moving, swivel or kinematic systems, etc.;

- formation of the architecture of high-rise buildings is based on creating spacialdimensional solutions and use of ecological methods of construction to provide comfortable microclimate in their closest vicinity and city-wide: accounting climatic conditions of the landscape by orientating in the building structure, selecting forms and other plastic tools;

- functional content of the high-rise buildings includes following types: hotel, commercial building, trade-amusement complex, residence complex, etc.;

- overall trend is towards sophistication of services from multifunctional building to multifunctional object, that allows considering high-rises as a promising type of buildings introducing solutions to many urban planning, architectural-constructional and social-economical tasks in the given construction, in the areas of reconstruction with a deficit of unoccupied city space and on the territories of new construction;

- in the conditions of global competition the construction of high-rise buildings is a way of promoting the brand of construction companies, investors, implementing innovative technologies. Astana's case once again proves a well-known truth - high-rise construction is a reputational project that provides multiplicative effect at the city level and even country level.

Some of the cons to constructing high-rises in Kazakhstan are: absence of the comprehensible energy saving architectural-constructional and energy-effective engineering-technological solutions that provide notable reduce in their operational costs; low use of regional imagery in the architecture of high-rise buildings.

Considering all of the aforementioned, the article uncovers and formulates urban planning and space-planning issues of forming the architecture of high-rise buildings in Kazakhstan: construction taking into account climatic, ecological requirements; need for compliance with urban planning requirements, providing architectural-spacial uniformity of the building, developing functional zoning and conditions of visual perception, etc.

\section{References}

1. V. A. Kharitonov, Design, construction and operation of high-rise buildings: Monograph, (Moscow, ASV publishing house, 2014)

2. Specifics of design and construction. High-rise buildings and other distinctive structures of China. Academic edition by: P.A. Akimov, V.N. Sidorov, A.R. Tusnin Translated from Chinese, 808 (Moscow, ASV publishing house, 2013) 
3. A. V. Dukart, A. I. Oleynik, Dynamic dampers of structure vibrations Edited by A.V. Dukart, 248 (Moscow, ASV publishing house, 2015)

4. G. E. Shablinski, Monitoring distinctive high-rise buildings and structures for dynamic and seismic effect Scientific edition, 328 (Moscow, ASV publishing house, 2013)

5. B. A. Glaudinov, M. G. Seydalin, A. S. Karpykov, Architecture of the Soviet Kazakhstan, 319 (Moscow Stroyizdat, 1987)

6. G. M. Kisamedin, Architecture of distinctive buildings, 212 (Almaty, Stroitelstvo i arkhitectura, 2012)

7. Meuser Ph. Kasachstan, 539 (Berlin: DOM publishers, 2015)

8. V. A. Khomyakov, Research of strength and stability of soil arrays autoref. diss... doctor of engineering, 37 (Almaty, 2010)

9. V. A. Khomyakov, Researches of Properties of Soil at Underground Construction in the City of Almaty Korea-Kazakhstan Joint Geotechnical Seminar Aug 21 - 22, 52-57 (Incheon, Republic of Korea, 2012)

10. V. A. Khomyakov, Researches of deformational characteristics of loess soil during three-dimensional compression for use in calculations of buildings and structures on seismic loads Theses of 7th Kazakhstani-Chinese int. symposium 'Forecast of earthquakes, assessment of seismic danger and seismic risk of Central Asia', 237-239 (Almaty, June 2-4, 2010)

11. Zhusupbekov A.Z. Research of bearing property of driven piles using dynamic probing // Bases, foundations and mechanics of soil. 2014. No. 2. - pp. 2932.

12. M. S. Abakanov, Low-cycle strength of reinforced concrete structures of framework buildings under loads like seismic, 132 (Almaty, KazNIISSA, 2016)

13. I. I. Vedyakov, D. V. Konin, P. D. Odesskiy, Steel frameworks of high-rise buildings: Scientific edition, 272 (Moscow, ASV publishing house, 2014)

14. Ph. Meuser, A. Dalbai, G. Herz Astana, 223 (Berlin, DOM publishers, 2015)

15. S. Kuc (CUT, Krakow, Poland), S. S. Sadykova (ENU Astana, Kazachstan), W.Kuc (AFM Krakow, Poland), The Architecture of Astana as the Example of Contemporary City Creation, Proc. of 3nd Annual International Conference of Architecture and Civil Engineering (ACE-2015), ISSN: 2301-394X, doi: 10.5176/2301-394X_ACE15.154, 2, 683-690 (Singapore, 2015)

16. A. Galimzhanova, M. Glaudinova, The history of the arts of Kazakhstan, 2, 192 (Almaty, Oner, 2011)

17. http://kazakhstanhotel.kz/ru/551-istorija.html

http://www.voxpopuli.kz/history/2249-pervyy-neboskreb-alma-aty.html (last accessed 2017.04.25)

18. http://www.almatymadeniet.kz/ru/home/pamyatniki/mestnogo-

znacheniya/arkhitekturnye/zdanie-vysotnoj-gostinitsy-kazakhstan (last accessed 2017.04.20)

19. The Registry of historical and cultural monuments of Almaty, Ed.in chief B.G. Ayagan, (Almaty, 'Kazak Entsiklopediyasi' LLP, 2006)

20. http://capitalpartners.ws/ru/index.php/snapshot/news/capital-partners-openedesentai-tower (last accessed 2017.04.29)

21. http://files.gisap.eu/sites/files/digest/95.indd\%20Internet.pdf (last accessed 2017.04.27) 
22. Meuser Ph. Aesthetik der Leere: modern Architektur in Zentralasien, 151 (Berlin, Braun, 2002)

23. A. S. Tchikanayev, Astana: architectural symphony of the Great Steppe, 270 (Astana, Delovoi Mir, 2008)

24. The master plan of Astana. 10 years, Ed.in chief S.Zhunysov, B.Dosmagambetov, 272 (Astana, Delovoy Mir Astana, 2011) 